\section{Author Index, Volume 76, 2000}

Adamowicz, Wiktor L. - See Akabua, Kojo M. et al.

Akabua, Kojo M., Wiktor L. Adamowicz and Peter C. Boxall.

C Spatial non-timber valuation decision support systems

Alexander, M.E. - See Thorburn, R.W. et al.

Alfaro, Rene I. - See Kimoto, Troy T.M. et al.

Anderson, Steven. - Preserving Canadian forest history: The role of the Forest History Society

Apsey, Mike, Don Laishley, Vidar Nordin et Gilbert Paillé. — La forêt perpétuelle: Les leçons du passé, un guide vers la durabilité des forêts canadiennes dans l'avenir

Apsey, Mike, Don Laishley, Vidar Nordin and Gilbert Paillé. -

The perpetual forest: Using lessons from the past to sustain Canada's forest in the future

Archambault, Louis. - See Laflèche, Vincent et al.

Backman, Charles A. - The Russian forest sector: Sun and shadows 159

Balsillie, David. - See Lautenschlager, R.A. et al.

Baskent, Emin Z., Glen A. Jordan and A.M.M. Nurullah. -

Designing forest landscape management

Baskent, Emin Zeki - See Nurullah, A.M.M. et al.

Beardmore, T. - See Mcllwrick, Ken et al.

Bell, F.W. - See Haddow, K.A. et al.

Bell, F. Wayne. - See Pitt, Douglas C. et al.

Bernier, P.Y. - See Fournier, R.A. et al.

Bhuie, A.K., D. McLaughlin and D.N. Roy. - Exposure of urban ecosystems to $\mathrm{Mn}$ and $\mathrm{Pb}$ contaminants from gasoline additives

beside a major highway in the Greater Toronto Area, Canada

Blenis, Peter V. - Post-spacing mortality of lodgepole pine from armillaria root disease

Borden, John H. - See Kimoto, Troy T.M. et al.

Bouthillier, Luc. - See Kneeshaw, Daniel D. et al.

Boxall, Peter C. - See Akabua, Kojo, M. et al.

Cameron, Don and David Dwyer. - Dr. G.W.I. Creighton - 75

years of leadership in forestry

Carignan, Richard. - See Kneeshaw, Daniel D. et al.

Carlsson, Lars, Mats-Olov Olsson and Nils-Gustav Lundgren. -

If money only grew on trees - The Russian fores sector in transition

Cathro, John and Sheri Walsh. - Tenure reform in British

Columbia: Developing tenure that benefits communities

Cayford, James H. - Constantly evolving: Constantly informing:

The Forestry Chronicle, 1925 - 1999

Caza, C.L. and D. Neave. - New millennium forestry and the fate of wildlife

Cherry, Marilyn L. - See Parker, William C. et al.

Chiu, M. - See McLaughlin, D.L. et al.

Claveau, Yves. - See Ruel, Jean-Claude et al.

Coady, Linda. - What I saw of the revolution: Reflections of a

corporate environmental manager in the $1990 \mathrm{~s} \mathrm{BC}$ coastal forest

industry

Colombo, Stephen J. - See Sampson, Paul H. et al.

Colombo, Stephen J. - See Parker, William C. et al.

Comeau, Phil. - See Ruel, Jean-Claude et al.

Csillag, F. - See Puric-Mladenovic, D. et al.

Davidson-Hunt, Iain. - See Duchesne, Luc. C. et al.

D'Eon, Robert G. and Susan M. Glenn. - Perceptions of landscape patterns: Do the numbers count?

Dey, Daniel C. and Richard P. Guyette. - Anthropogenic fire

history and red oak forests in south-central Ontario

Dickson, E.E. - See Franklin, S.E. et al.

Doucet, René. - See Ruel, Jean-Claude et al.

Doucet, René. - See Kneeshaw, Daniel D. et al.

Drapeau, Pierre. - See Kneeshaw, Daniel D. et al.

Duchesne, Luc. C., D.G. Herr, S. Wetzel, I.D. Thompson and R.

Reader. - Effect of seed predation, shade and soil organic matter on

the early establishment of eastern white pine and balsam fir seedlings 759

Duchesne, Luc C., John C. Zasada and Iain Davidson-Hunt. -

Nontimber forest product industry in Canada: Scope and research

needs

Durigon, D. - See McLaughlin, D.L. et al.

Dwyer, David. - See Cameron, Don

Elioff, John D. - See Stone, Douglas M.

Emmett, Brian. - Managing for sustainable development: 99\% perspiration

Emmett, Brian. - La gestion du développement durable: $99 \%$ de transpiration
Farnden, Craig. - Simulated conversion of unmanaged interior spruce-subalpine fir stands to a regulated uneven-aged structure

Farr, D.R. - See Franklin, S.E. et al.

Fisher, D. - Forestry and foresters through The Forestry Chronicle 596

Flannigan, Michael D. - See Parker, William C. et al.

Forbes, K. - See Mcllwrick, Ken et al.

Fournier, R.A., L. Guindon, P.Y. Bernier, C.-H. Ung and F.

Raulier. - Spatial implementation of models in forestry

Franklin, S. E., E. E. Dickson, D.R. Farr, M.J. Hansen and L.M. Moskal. - Quantification of landscape change from satellite remote sensing

Freemantle, Jim. - See Sampson, Paul H. et al.

Gauthier, Sylvie. - See Kneeshaw, Daniel D. et al.

Glenn, Susan M. - See D'Eon, Robert G.

Guindon, L. - See Fournier, R.A. et al.

Guyette, Richard P. - See Dey, Daniel C.

Haddow, K.A., D.J. King, D.A. Pouliot, D.G. Pitt and F.W. Bell.

- Early regeneration conifer identification and competition cover assessment using airborne digital camera imagery

Hall, J. Peter. - The issue of scale in the aggregation of data on indicators of Sustainable Forest Management from subnational to national levels

Hall, R.J., D.R. Peddle and D.L. Klita. - Mapping conifer understory within boreal mixedwoods from Landsat TM satellite imagery and forest inventory information

Hall, R.J. - Preface: Applications of remote sensing to forestry Current and future

Hansen, M.J. - See Franklin, S.E. et al.

Hardy, Yvan. - Imagining the next millennium

Hardy, Yvan. - Imaginer le prochain millénaire

Hartridge, Chris. - See Kozak, Robert

Hawley, Alex. - See Robson, Mark et al.

Hayhurst, Doug. - Avoiding the petrified forest

Herr, D.G. - See Duchesne, Luc. C. et al.

Higginbotham, Ken. - Environmental issues in forestry 2000

Hollstedt, Chris. - See Lautenschlager, R.A. et al.

Howe, C.D. - Some aspects of our forestry problem

Idziak, C. - See Kenney, W.A.

Irving, Denzil. - See Sampson, Paul H. et al.

Jordan, Glen A. - See Baskent, Emin Z. et al.

Jordan, Glen A. - See Nurullah, A.M.M. et al.

Keenan, Vince. - See Wang, G. Geoff et al.

Kenney, W.A. - Leaf Area Density as an urban forestry planning and management tool

Kenney, W.A. and C. Idziak. - The state of Canada's municipal forests - 1996 to 1998

Kenney, W.A. - See Puric-Mladenovic, D. et al.

Kenney, W.A. - See van Wassenaer, P.J.E. et al.

Keyes, Christopher R. - Natural regeneration of ponderosa pine: Pest management strategies for seed predators

Kimoto, Troy T.M., Rene I. Alfaro and John H. Borden. - Past infestations of the white pine weevil in naturally regenerating spruce stands

King, Douglas J. - Airborne remote sensing in forestry: Sensors, analysis and applications

King, D.J. - See Haddow, K.A. et al.

Klita, D.L. - See Hall, R.J. et al.

Kneeshaw, Daniel D., Alain Leduc, Pierre Drapeau, Sylvie

Gauthier, David Paré, Richard Carignan, René Doucet, Luc

Bouthillier and Christian Messier. - Development of integrated ecological standards of sustainable forest management at an operational scale

Kozak, Robert and Chris Hartridge. - Shared facilities: A model for forest-dependent communities in British Columbia

Kranabetter, J.M. and D. Yole. - Alternatives to broadcast burning in the northern interior of British Columbia: Short-term tree results Krcmar-Nozic, Emina. - See van Kooten et al.

Laflèche, Vincent, Jean-Claude Ruel et Louis Archambault. Évaluation de la coupe avec protection de la régénération et des sols comme méthode de régénération de peuplements mélangés du domaine bioclimatique de la sapinière à bouleau jaune de l'est du Québec, Canada

Laishley, Don. - See Apsey, Mike et al.

Lautenschlager, R.A. - Can intensive silviculture contribute to sustainable forest management in northern ecosystems? 
Lautenschlager, R.A., Holly MacLeod, Chris Hollstedt and David Balsillie. - Examining the Specifics approach to identifying indicators of sustainable natural resource management in Ontario, Saskatchewan, and British Columbia

Lawton, Kenneth and Wiken, Ed B. - Understanding wildlife habitats in urban areas

Leduc, Alain. - See Kneeshaw, Daniel D. et al.

LeMay, Valerie. - See Staudhammer, Christie

Lewis, Kathy J. and B. Staffan Lindgren. - A conceptual model

of biotic disturbance ecology in the central interior of B.C.: How

forest management can turn Dr. Jekyll into Mr. Hyde

Liljalehto, H. - See McLaughlin, D.L. et al.

Lindgren, B.S. - See Lewis, Kathy J.

Lundgren, Nils-Gustav. - See Carlsson, Lars

MacLeod, Holly. - See Lautenschlager, R.A. et al.

MacMillan, A. - See Thorburn, R.W. et al.

McAlpine, Robert S. - See Parker, William C. et al.

McIlwrick, Ken, S. Wetzel, T. Beardmore and K. Forbes. -

Ex situ conservation of American chestnut (Castanea dentata

(Marsh.) Borkh.) and butternut (Juglans cinerea L.), a review

McIntyre, Bruce. - A view to the future - Forestry in the new millennium

McKenney, Dan. - What's the economics of intensive silviculture? 275

McLaughlin, D.L., M. Chiu, D. Durigon and H. Liljalehto. -

The Ontario Hardwood Forest Health Survey: 1986-1998

McLaughlin, D. - See Bhuie et al.

McManus, E. Craig. - Mutual trust and mutual gains: A recent

Crown land use planning exercise in Ontario

Messier, Christian. - See Kneeshaw, Daniel D. et al.

Messier, Christian. - See Ruel, Jean-Claude et al.

Meunier, S. - See Ruel, J.-C. et al.

Miller, John R. - See Sampson, Paul H. et al.

Mohammed, Gina H. - See Sampson, Paul H. et al.

Moskal, L.M. - See Franklin, S.E. et al.

Neave, D. - See Caza, C.L.

Noland, Thomas L. - See Sampson, Paul H. et al.

Nordin, Vidar. - See Apsey, Mike et al.

Nurullah, A.M.M. - See Baskent, Emin Z. et al.

Nurullah, A.M.M., Glen A. Jordan and Emin Zeki Baskent. -

Spatial stratification in forest modelling

Olsson, Mats-Olov. - See Carlsson, Lars

Paillé, Gilbert. - See Apsey, Mike et al.

Papadopol, C.S. - Impacts of climate warming on forests in

Ontario: Options for adaptation and mitigation

Papadopol, Chris. - See Parker, William C. et al.

Paré, David. - See Kneeshaw, Daniel D. et al.

Parker, William C., Stephen J. Colombo, Marilyn L. Cherry,

Michael D. Flannigan, Sylvia Greifenhagen, Robert S.

McAlpine, Chris Papadopol and Taylor Scarr. - Third

Millennium Forestry: What climate change might mean to forests

and forest management in Ontario

Peddle, D.R. - See Hall, R.J. et al.

Philippot, Daniel. - See Wang, G. Geoff et al.

Pineau, Marius. - See Raymond, Patricia et al.

Pinto, Fred. - Creating a forestry language

Pitt, D.G. - See Haddow, K.A. et al.

Pitt, Douglas G., Ulf Runesson and F. Wayne Bell. - Application of large- and medium-scale aerial photographs to forest vegetation management: A case study

Podlubny, Don. - A milestone in the new millennium

Pouliot, D.A. - See Haddow, K.A. et al.

Puric-Mladenovic, D., W.A. Kenney and F. Csillag. — Land development pressure on peri-urban forests: A case study in the Regional Municipality of York

Quine, C.P. - See Ruel, J.-C. et al.

Raulier, F. - See Fournier, R.A. et al.

Raymond, Patricia, Jean-Claude Ruel et Marius Pineau. - Effet d'une coupe d'ensemencement et du milieu de germination sur la régénération des sapinières boréales riches de seconde venue du Québec

Reader, R. - See Duchesne, Luc. C. et al.

Roberts, Ralph W. - International perspectives

Roberts, Ralph W. - Perspectives internationales

Robson, Dave. - See Robson, Mark et al.

Dobson. - Comparing the social values of forest-dependent, provincial and national publics for socially sustainable forest management

Roy, D.N. - See Bhuie et al.

Ruel, Jean-Claude. - See Raymond, Patricia et al.

Ruel, Jean-Claude. - See Laflèche, Vincent et al.

Ruel, J.-C., C.P. Quine, S. Meunier and J. Suarez. - Estimating windthrow risk in balsam fir stands with the ForestGales model

Ruel, Jean-Claude, Christian Messier, René Doucet, Yves

Claveau and Phil Comeau. - Morphological indicators of growth response of coniferous advance regeneration to overstorey removal in the boreal forest

Runesson, Ulf. - See Pitt, Douglas C. et al.

Sampson, Paul H., Gina H. Mohammed, Pablo J. Zarco-Tejada, John R. Miller, Thomas L. Noland, Denzil Irving, Paul M. Treitz, Stephen J. Colombo and Jim Freemantle. - The bioindicators of forest condition project: A physiological, remote sensing approach

Scarr, Taylor. - See Parker, William C. et al.

Schaeffer, L. - See van Wassenaer, P.J.E. et al.

Siemens, J. Aurea. - See Wang, G. Geoff et al.

Staudhammer, Christie and Valerie LeMay. - Height prediction

equations using diameter and stand density measures

Stennes, Brad. - See van Kooten et al.

Stone, Doulgas M. and John D. Elioff. - Soil disturbance and

aspen regeneration on clay soils: Three case histories

Suarez, J. - See Ruel, J.-C. et al.

Thompson, I.D. - See Duchesne, Luc. C. et al.

Thorburn, R.W., A. MacMillan and M.E. Alexander. - The application of interactive multimedia CD-ROM technology to wildland fire safety training

Treitz, Paul M. - See Sampson, Paul H. et al.

Ung, C.-H. - See Fournier, R.A. et al.

van Kooten, G. Cornelis, Brad Stennes, Emina Krcmar-Nozic and Ruud van Gorkom. - Economics of afforestation for carbon sequestration in western Canada

van Wassenaer, P.J.E., L. Schaeffer and W.A. Kenney. -

Strategic planning in urban forestry: A 21 st century paradigm shift for small town Canada

van Gorkom, Ruud. - See van Kooten et al.

Wagner, Robert G. - Competition and critical-period thresholds

for vegetation management decisions in young conifer stands

Walsh, Sheri. - See Cathro, John

Wang, G. Geoff, J. Aurea Siemens, Vince Keenan and Daniel

Philippot. - Survival and growth of black and white spruce seedlings in relation to stock type, site preparation and plantation type in southeastern Manitoba

Wetzel, S. - See Duchesne, Luc C. et al.

Wetzel, S. - See McIlwrick, Ken et al.

Wiken, Ed B. - See Lawton, Kenneth

Wood, A.D. - Experimental studies of potential improvements in the forest regeneration capabilities of "seed-containing aerial darts" Yole, D. - See Kranabetter, J.M.

Zarco-Tejada, Pablo J. - See Sampson, Paul H. et al. 